\title{
The effect of leadership ethics and climate cooperation on job satisfaction of employees in education office of West Sumatera province
}

\author{
Nova Wilia ${ }^{1}$, Nurhizrah Gistituati ${ }^{2}$, Rifma $^{3}$ \\ ${ }^{123}$ Universitas Negeri Padang, Padang - Indonesia, (novawilia@rocketmail.com)
}

\begin{abstract}
Field observations found that job satisfaction of employees in West Sumatera Provincial Education Office is still low. This is allegedly due to the influence of leadership ethics and cooperation climate, then conducted research to test the truth. This study aims to reveal the influence of leadership ethics and cooperation climate on employee job satisfaction in Education Office of West Sumatera Province. Hypothesis proposed in this research are: 1); there are influence of leadership ethics on cooperative climate, 2) there is influence of leadership ethics and cooperation climate to employee job satisfaction. Population in this research is all officer of Educational Department of West Sumatera Province with status of civil servant. The population is 300 people and the sample size is 73 people. Collecting data using Likert scale questionnaire that has validi and reabel. Data analysis using correlation and regression techniques. The result of data analysis shows that: 1) leadership ethics have an effect on cooperation climate equal to $63.50 \%$, 2) leadership ethics influence to job satisfaction of employee equal to $55.80 \%$ and cooperation climate influence to employee job satisfaction equal to $37.40 \%$.
\end{abstract}

Keywords: influence, leadership ethics, cooperation climate, job satisfaction

\section{Introduction}

Job satisfaction can affect the behavior of individuals within the organization. The Bavendam Research Center which has measured job satisfaction with surveys to employees, in the view that employees who have high job satisfaction will: a) believe that in the work process, the organization will provide job satisfaction, b) care for the quality of its work, c) more attached to organization, d) have high speed, and e) more productive (Sinambela, 2012: 260).

Job satisfaction reflects a person's attitude towards his work. If a person is positive about his work, he will get a feeling of satisfaction. Conversely, if a person behaves negatively (dislikes), then he will feel dissatisfied with what he has done. Usman (2008: 464) states that job satisfaction is a person's attitude toward his work that reflects a pleasant and unpleasant experience in his work and his expectations for future experiences. Anoraga (2006: 79) argues that usually people will feel satisfied with the work he has or is currently doing, if what he did was considered to have met his expectations in accordance with the purpose of his work. 
Individuals who are satisfied with their work can improve their motivation; while dissatisfied individuals will have an impact on behavior in the form of high absence, job change, strike, low organizational sense, sabotage, and stealing (Gistituati, 2009: 307). Someone who has job satisfaction will be more motivated to work well, work with passion and always try to make his work better. This indirectly impacts on the increase of work performance and employee productivity so that the organization's goals that have been set well achieved.

However, since the 1970s, there have been many social changes that have led to widespread claims that job satisfaction is greatly decreased due to dramatically increased employee expectations, the pattern of labor changes when young people, women, and minorities seek employment (Sinambela, 2012: 261 ). Based on the temporary observations that were supplemented with some information from the staff through the interviews, there were several problems in the Education Office of West Sumatera Province indicating that the low level of employee job satisfaction. This problem appears from several phenomena, namely: employees complain when working, employees look less happy when working, while working employees are worried, and there are still employees who seem less active and not eager. The problems arise because the many factors affect job satisfaction. From the phenomenon appears the factors that allegedly affect employee job satisfaction is the ethics of leadership and the climate of employee cooperation. The importance of job satisfaction for person and the emergence of problems in the field indicate that the low level of employee job satisfaction is special attention for researcher. So it is necessary to conduct research on employee job satisfaction and factors that contribute to job satisfaction.

\section{Method}

The population comes from all employees in West Sumatra Provincial Education Office which amounts to 300 people. The sample was taken using stratified proportional random sampling technique which amounted to 73 people.

Research variable consist of two variables that is independent variable (independent variable) and dependent variable (variable dependent). The independent variable in this research is supervisor leadership and work motivation of employee, while the dependent variable in this research is employee work discipline. In this study the instrument used to collect data is a questionnaire with Likert Scale Model. The instruments in this study have been tested for validity and reliability. Data were analyzed using correlation technique, simple regression and path analysis to test hypothesis.

\section{Results and Discussion}

\section{The Effect of Leadership Ethics on Climate Cooperation}

Cooperation is a tool to overcome the limitations of individuals. Individual behavior in the organization creates a state that gives effect to the continuity of the organization with a series of goals that must be realized. It is very important to align and condusive cooperation climate. Hadiyanto (2016: 4) suggests that the climate is any situation that arises due to a relationship that can affect the process of an organisation on activity.

Based on the results of this research analysis provides information, that leadership ethics (X1) directly affect the climate of cooperation (X2) of 0.635 . in an effort to improve the climate of cooperation in order to become more conducive can be guidance on the compactness of employees. Johnson in Zulkarnain (2013) states that the key to cooperation is positive interdependence, individual accountability, supportive interaction, social skills and group processes. This is supported by Setiyanti (2012: 61):

Cooperation of groups within organizations or companies can also be realized with the existence of coaching work relations, either working relationships between members of the organization or company or between the leadership of the organization or company with subordinates or other members. The goal of 
fostering working relationships within an organization or company is the achievement of a harmonious and coherent cooperation between members of the organization or existing human resources. Establishment of working relationships conducted by the leadership of the organization or company is said to succeed if the creation of cooperation between members of the organization or human resources in the organization or company.

Cohesiveness is one indicator in working together at the organization and is needed so as to facilitate the implementation of activities to achieve goals. Good group leadership can foster a sense of togetherness among group members, and can neutralize any differences that exist within the group. Thus, the sense of belonging and cohesiveness of the group in cooperation is higher, as the climate of cooperation is more conducive. Many things related to leadership one of them is leadership ethics. Thomas in Zulkarnaian (2013: 60) suggests factors that affect group cohesiveness, namely: a) group leadership, b) group membership, c) group goal values, d) homogeneity of group members, e) cohesiveness of group activities, and $f$ ) number of members group.

Leader behavior should be balance with the ethics of leadership; it can influence and support the conducive to climate of cooperation. Leadership ethic is applied by a leader in ethical behavior to demonstrate good values and ethics in working. It will create conducive and enjoyable working climate because employees will imitate a leader's behavior to be good workers, so employees will feel comfortable and calm and motivate to be better workers, so that employees will get job satisfaction.

Based on the results above, it can be concluded that the leadership is done in accordance with the norms and leadership ethics in conducting co-operation, created a conducive to cooperation. The conducive to climate made better employment, motivate employees, and provided high job satisfaction indirectly.

\section{Leadership Ethics and Climate Cooperation on Employee Job Satisfaction}

Employee job satisfaction is very important because it can increase employee productivity. With job satisfaction employees have a feeling of fun in work, and motivated to work better. From the results of research shows that job satisfaction of employees in the Office of Education of West Sumatra Province is quite high with a score of $79.68 \%$. So the job satisfaction of employees should be uplifted because it can have an impact on the productivity of the institution. From the indicators used found that the feeling of relief in working to be the lowest indicator with a score of $71.40 \%$. Head of Education Office should strive to improve employee job satisfaction in the Education Office of West Sumatra Province for employee work productivity to be high in achieving the goals of the institution.

Efforts to improve employee job satisfaction can be done through the factors that influence it. This is supported by Happock in Polem (2002: 204) said the factors that affect job satisfaction are the climate of cooperation, work performance, work motivation, security and safety, incentives or salary and leadership ethics of superiors. Of the many factors that influence the found factors of leadership ethics and cooperation climate that influence the employee's job satisfaction.

\section{Leadership Ethics on employee job satisfaction}

Leadership ethics are standard of behavior that contains moral values that must be upheld by the leader through his actions as a leader and themselves as people who become the frame of reference in decision making. With leadership ethics a leader can be critical, rational, dare to express his own opinions, be firm in accordance with the sense of ethical responsibility to oneself and subordinates. This means that the leadership can present itself as an example for all of its people. So that employees as followers work maximally, thereby increasing motivation, work ethic and job satisfaction of followers.

By applying leadership ethics through ethical behavior a leader can carry out leadership functions that run on ethical principles in accordance with the values adopted by the organization. Ethical leadership will create a more comfortable working environment within the organization, higher productivity and able to resolve existing conflicts within the organization so that employee job satisfaction is obtained.

In an effort to increase employee job satisfaction can be done by increasing the application of leadership ethics to create a conducive working climate. As revealed from the results of research, found that 
leadership ethics directly affect employee job satisfaction of 0.321 and leadership ethics (X1) also indirectly affect employee job satisfaction $(\mathrm{Y})$ through cooperation climate (X2) of 0.237.

Leaders should strive to optimize employee job satisfaction by better understanding and trying to apply leadership ethics in accordance with the norms and rules that apply so that employee job satisfaction is even better. According to Sutrisno (2010: 90) asserted that leaders in the organization become role models for employees, so that employees will mimic the behavior that leaders see every day. That is, if leaders show behavior that is less in accordance with the rules and norms that are not in accordance with leadership ethics in leading employees, will create an unpleasant atmosphere, and can affect employees in work so that employee job satisfaction is not met properly. Improving leadership ethics can be done directly to employees to improve employee job satisfaction that is by way of more respect for employees, serve employees well when finishing the job, being fair to employees, and honest.

The results of the study found that the service behavior is the lowest indicator by score of $72.75 \%$ which is in the high category. So that, the leadership ethics implementation should increase in the Provincial Education Office of West Sumatra done through improving service others. The altruistic leader (based on the interests of employees) which strongly prioritize the well-being of followers. In implementing the principle of service, leader must be willing to focus on followers, must place the interests of employees, and must act to benefit employees. The efforts are accompanying employees to work, empowering, team building, showing socially behavior, eliminating discrimination and social injustice, listening to employee complaints, showing empathy for employees and accepting unconditionally.

\section{Climate cooperation Against Job Satisfaction Employees}

If seen from the data analysis of the relationship between the climate of cooperation and employee job satisfaction, the increasingly increasing climate of cooperation will have an impact on the employee morale in carrying out the task. The better the cooperation climate the higher the employee morale. It will also improve the quality of achieving organizational goals to be more effective and efficient as expected. This opinion is supported by Syafaruddin (2002: 71) "Psychology theory confirms that groups with high team spirit work better than those with little team spirit, which means that the spirit of teamwork should be built within the organization."

Increased employee job satisfaction is one of them is by improving the climate of cooperation, because with a conducive climate employees openly mutual, respect each other, respect each other, put the interests together, and the establishment of intimate relationships. That way employees will work harder, more excited, more passionate and better so as to get maximum results. But in reality the climate of cooperation in the Education Office of West Sumatera Province still needs to be improved again, because it is found that there are still employees who have a careless attitude towards colleagues, prioritizing personal interests, negative thoughts arise when colleagues provide assistance, ASN attitude that lowers the power of Non ASN , fellow ASN rivalry and non-ASN rivalry that creates conflict.

The results of this study indicate that the achievement of cooperation climate Education Office of West Sumatra Province needs to be improved especially in terms of cohesiveness because it is in the less good category. Cohesiveness is needed to maximize teamwork performance. Cohesiveness is characterized by strong relationships among team members who feel the dependence of each other in the task sequence, the dependence on the results they want to achieve and the high commitment as part of a team. Teamwork is self-selected by some who raise their own team mates and social ways after work can stimulate socioemotional cohesion. Helping socio-socio-cohesion development needs to be balanced with team cohesiveness (Dewi, 2007: 51).

Efforts that can be made to improve the climate of cooperation can be done through increasing the cohesion indicator which is the lowest indicator of cooperation climate. Cohesiveness in an organization must be maintained and enhanced. The thing that can be done is to foster cohesiveness, among others; create a sense of shared vision and mission so that members will themselves be united by the vision and mission itself, creating mutual trust through an atmosphere of openness and building effective communication. 
With the high climate of employee cooperation, the quality of the work is better and can improve employee job satisfaction. Conducive climate of cooperation will provide high morale to the employees to do their work in order to realize organizational goals, so that job satisfaction will increase employees.

\section{Work with Graphic:}

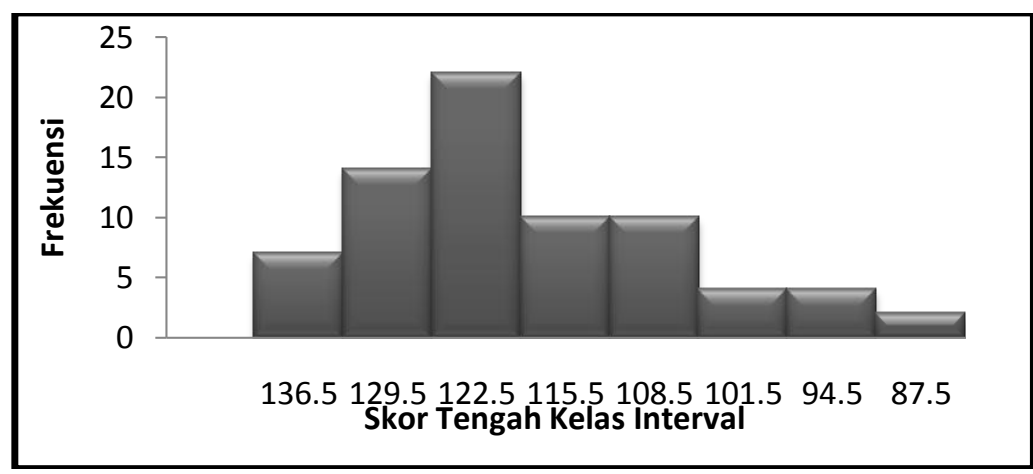

Figure 1: Employee Satisfaction Histogram

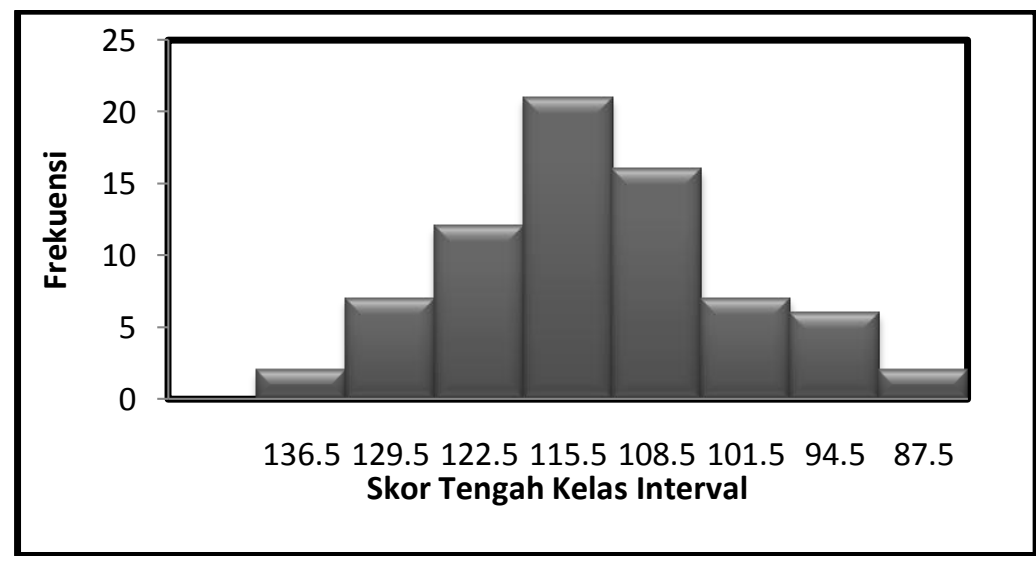

Figure 2: Histogram Ethics of Leadership

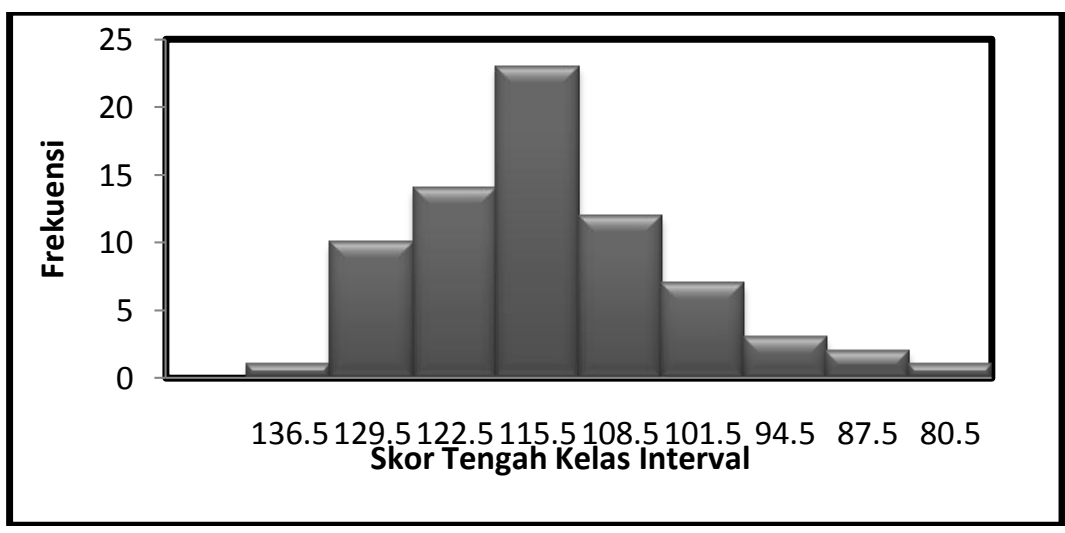

Figure 3. Climate Histogram Cooperation (X2)

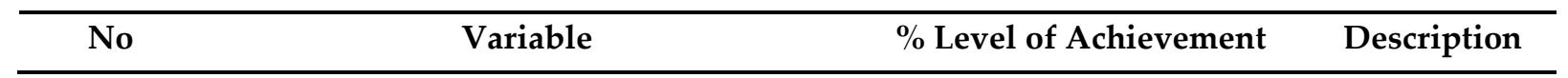




\begin{tabular}{clcc}
\hline $\mathbf{1}$ & Job Satisfaction & 79,68 & High enough \\
$\mathbf{2}$ & Leadership Ethics & $75.24 \%$ & Good enough \\
$\mathbf{3}$ & Climate Cooperation & 82.25 & Conducive \\
\hline
\end{tabular}

Tabel $1<$ Recapitulation of Research Data on Leadership Ethics, Climate Cooperation, and Job Satisfaction in Education Office of West Sumatera Province >

Tabel $2<$ Summary The decomposition of path coefficients, direct and indirect influences, and total influence on the influence of leadership ethics (X1) and cooperation climate (X2) on employee job satisfaction $(\mathrm{Y})>$

\begin{tabular}{cccc}
\hline Influence of Variables & \multicolumn{2}{c}{ Causal Influence } & Total \\
\cline { 2 - 3 } & Directly & Not Direct Through X2 & \\
X1 terhadap Y & 0.321 & 0.237 & 0.558 \\
X2 terhadap Y & 0.374 & - & 0.374 \\
\hline
\end{tabular}

\section{Conclusions}

Based on the results of data analysis can be concluded as follows: 1) Leadership ethics (X1) directly affect the climate of cooperation (X2) of $63.50 \%$. The better the application of leadership ethics in each unit then the better the Climate of cooperation; 2) Job satisfaction can be improved through the Leadership Ethics and Climate cooperation. Where leadership ethics (X1) affect the job satisfaction (Y) with a total of $55.80 \%$ where the direct influence of $32.10 \%$ and the indirect effect of $23.70 \%$. Climate cooperation (X2) directly affect the job satisfaction (Y) of $37.40 \%$.

\section{Acknowledgments}

On this occasion I would like to thank the parties: 1) Prof. Dr. Nurhizrah Gistituati, M.Ed., Ed.D. and Dr. Rifma, M.Pd. as a mentor; 2) Dr. Hadiyanto, M.Ed., Dr. Hanif Alkadri, M.Pd., and Dr. Ir. Jasrial, M.Pd. as a tester; 3) Parents (M. Yatim \& Desri Awida), husband (Rio Putra, S.Kep) and beloved siblings (Rahmita Putri, A.Md. and Elsi Triani; 4) Father and Mother in the Department of Education Administration FIP UNP; 5) Zizvi Rilian Ramadona and Novebri.

\section{References}

Dewi, S. (2007). Teamwork (Cara Menyenangkan Membangun Tim Impian). Bandung: Progressio. Gistituati, N. (2009). Manajemen Pendidikan: Landasan Teori dan Perkembangannya. Padang: UNP Press. Hadiyanto. (2016). Teori dan Pengembangan Iklim Kelas \& Iklim Sekolah. Jakarta: Kencana. Northouse, P. G. (2013). Kepemimpinan Teori dan Praktik. Jakarta: PT. Indeks. Sinambela, L. P. (2012). Kinerja Pegawai; Teori, Pengukuran dan Implikasi. Yogyakarta: Graha Ilmu. Usman, H. (2011). Manajemen Teori, Praktik, dan Riset Pendidikan. Jakarta: Bumi Aksara. Zulkarnain, W. (2013). Dinamika Kelompok: Latihan Kepemimpinan Pendidikan. Jakarta: Bumi Aksara. 